\title{
FIFTY SHADES OF TRANSLATION: ON THE PATTERNS IN THE ENGLISH TO POLISH TRANSLATION OF EROTICA
}

\author{
PATRYCJA KARPIŃSKA \\ Institute of English Studies, University of Wroclaw, \\ ul. Kuźnicza 22, Wrocław, Poland \\ E-mail address: patrycja.karpinska@uwr.edu.pl \\ ORCID: 0000-0003-3054-2874 \\ JĘDRZEJ OLEJNICZAK \\ Institute of English Studies, University of Wroclaw, \\ ul. Kuźnicza 22, Wrocław, Poland \\ E-mail address: jedrzej.olejniczak@uwr.edu.pl \\ ORCID: 0000-0003-4977-5459
}

\begin{abstract}
Aim. The aim of this article is to investigate the patterns in the translation of sex-related vocabulary from English to Polish in search for any changes regarding the markedness, poetics, and linguistic variety.

Methods. The study is conducted on the pairs of English erotic novels and their Polish translations. It involves both quantitative (corpus-based methods) and qualitative (Descriptive Translation Studies) methods.

Results. The results indicate significant change in the area of marked vocabulary. In English-Polish translation, a vast majority of the marked vocabulary related to sex is replaced with unmarked vocabulary, paraphrased, or simply deleted. The qualitative analysis also suggests certain changes in the poetics of text, introduced by the means of addition. These changes mostly result in sexual encounters becoming more romanticised in translation.

Conclusions. While the observed trends in translation are unmistakeable, it cannot be concluded with certainty what have led to the changes of the source text. Since the analysed texts were all published around the same time, by different publishing houses, and were translated by different translators, we are leaning towards the hypothesis of self-censorship in translation.
\end{abstract} norms

Key words: corpus-based study, Toury, erotica, sex-related language, translational 
$\mathrm{T}$ The publication of 50 Shades of Grey and the following storming entry of erotica into canon of popular literature have contributed to numerous sociological, psychological, or literary analyses. However, it does not seem to be also true for Translation Studies, even though many of those best-selling novels were translated into thirty or forty other languages. There are prolific studies on how the text changes due to cultural differences, political circumstances, systemic discrepancies: yet not many of those scrutinise the literature of erotica. Hence, even before we started our research, we had no doubts that the texts of this genre will be subject to numerous alterations: all translations are, and this text type touches upon particularly sensitive and highly regulated issue, which is the approved image and realisation of sexuality. We have decided to establish how specifically these alterations are realised, especially in terms of sex-related vocabulary, sensitive language, and text poetics. Our study is framed by the theory of translational norms as proposed by Gideon Toury (1995) and Theo Hermans (1995). In order to find answer to our research question, we applied both quantitative and qualitative research methods, as they allowed us to investigate the issue from more than one perspective and complemented each other.

\section{TRANSLATIONAL NORMS}

While a person's sexuality is connected with the sphere of privacy and intimacy, it is also subject to profoundly strict social control. Private and public, biology and culture: when it comes to the issue of sexuality, they are both two sides of the same coin. As John DeLamater writes, "while the potential for sexual behavior is provided by human biology, cross-cultural research has made it clear that sociocultural factors determine how that potential is expressed" (1981, p. 263). These sociocultural factors regulate first real world human encounters, yet not only; they influence also the manner in which sexuality is represented in sociocultural products, such as literature. The situation becomes even more layered once we take into account translation of literature and the fact that original text and its translation belong to two different sociocultural spheres and, hence, are subject to two different sets of regulations. This issue-however, not necessarily in the immediate context of sexuality-did not escape the attention of Translation Studies. It seems to be best captured by the notion of translational norms.

The concept of translational norms was first introduced by Gideon Toury, who today remains one of the key scholars in the field of Translation Studies (see Bukowski, \& Heydel, 2009, p. 205). One of the most revolutionary elements of his theory was that he treated translations as "facts of the culture which hosts them" (Toury, 1995, p. 24), hence introducing target-oriented approach to Translation Studies. What the target-oriented approach implies is that translation is initiated by, as well as created and later embedded in a system different to the source one, in which the original text functioned. From 
this stance, the process of translation is also the process of reciprocal change: a target culture changes the text in translation, yet the translation changes also the target culture (Toury, 1995).

When it comes to translation and translational norms, in every act of translation, there are at least two sets of norms involved: source and target. While some of the norms in both systems will converge, others will diverge even to the point of utter disagreement (Toury, 1995). This point of divergence is when the first of G. Toury's norms comes into play, namely the initial norm, which denotes the decision whether to follow the norms pertaining to the source or the target culture. If a translator chooses the first option, the result is so-called adequate translation, which does also involve possible tensions between the translation and its target system. If a translator chooses the second option, the result is so-called acceptable translation. Both choices entail shifts in the translation in regard to the original; the realisation of these shifts depends on the norms.

Apart from initial norms, G. Toury (1995) distinguishes two other types thereof: preliminary norms and operational norms. Preliminary norms deal with translation policy, hence the choice of texts that should be transferred into the target system, and directness of translation, hence the acceptability of indirect translation, i.e. the translation conducted on the basis of another translation. Preliminary norms, therefore, regulate the actions undertaken before the action of translation itself. Operational norms, on the other hand, regulate the very act of translation. G. Toury (1995) distinguishes two types of operational norms: matricial norms and text-lingual norms. In short, matricial norms regulate the structure of the text, including issues such as the completeness of a text, its division into particular segments, and the placements of these segments. Text-lingual norms influence the language aspect of translation. These norms establish a model for a translator, which guides him or her through the process of translation, advising on the preferable or inferior choices. Importantly, the said model depends also on the initial norm and it may be based on target norms, source norms, or both.

G. Toury (1995) himself was well-aware of some issues arising from the concept of translational norms. Firstly, there is the issue of the sociocultural boundedness of norms, meaning that norms not only highly depend on their sociocultural context but also that this context may vary greatly even in one society or that there may be more competing norms. Secondly, the norms are unstable; their change may be slow or quick but it is inevitable, and what is more, translators take an active part in this process. Thirdly, the act of extraction of translational norms is utterly difficult as they are not available themselves. Translation Studies scholars have access only to the product (i.e. the translation) governed by the norms but not only. Propaganda, translator's personal interests and skills, time and place constraints, etc-all these elements played their part in the final shape of translation as well. Other scholars attempted at the criticism of G. Toury's translational norms as well, pointing out issues such as the difficulty with the dichotomy 'adequacy' and 'acceptability' (Hermans, 
2009); simplicity of the initial norm and lack of emphasis on the compromise between the source and target norms, which without any doubt is the most common situation (Hermans, 2009); lack of emphasis on the human factor in translation (Pym, 1998); or the very tentative nature and multiplicity of explanations regarding certain recurring patterns in translation that could be identified as norms (Pym, 1998). Nevertheless, even taking into account these flaws, G. Toury's translational norms remain one of the most influential theories in Translation Studies.

After G. Toury, several other scholars undertook the issue of norms in their work. One of them is Theo Hermans, the father of sociocultural norms in Translation Studies. Similarly to the previously discussed theory, T. Hermans (1996) claims that norms come at play already at the level of transfer of given cultural products and then inform the process until its very end, however they are most significant during the act of translation itself. T. Hermans's norms are only one of many factors influencing translation and their role is rather advisory than anything else (e.g. which translation strategies or techniques should be applied, how a target text should be construed). It is worth noting here that while T. Hermans claims that there are numerous other factors affecting translation, he also writes that "[i]f it were not [for norms], translators faced with a source text, however short and simple, would either be unable to opt for one solution rather than another and throw their hands in despair, or make entirely random decisions, like a computer gone haywire" (1996, p. 28), hence introducing certain contradiction in his own theory.

Sociocultural norms are discussed from the communicative perspective, in which translation is defined as one of the forms of communication (Hermans, 1996). T. Hermans analyses norms in general placing them on continuum conventions - norms - rules - decrees, where conventions are the least obliging and, if broken, not punished, and decrees the most obliging, outrightly stated and, if broken, severely punished. He distinguished two types of norms: constitutive and regulative. Constitutive norms regulate what constitutes a translation; hence, it is due to those norms that certain texts are deemed translations, whereas others adaptations. Regulative norms regulate what comprises the notion of correct translation (Hermans, 1996). The situations in which only one rule binds the social actor are highly unlikely; there are usually numerous applicable norms and it is up the said actor to choose which one to follow. Unlike in the above-discussed theory, for T. Hermans (1996) norms are also carriers of (social) values, which are tightly related to the power relations and social structures in which the actor functions.

While T. Hermans's sociocultural norms (1996) indeed demonstrate a close relationship between translational norms and social norms, his work has been often criticised. Perhaps the main allegation against T. Hermans is that his theory is too abstract to be applied in research and it adds to the already existing gap between theory and practice in Translation Studies (Chesterman, 1998). Furthermore, Anthony Pym argues that T. Hermans's theory has moved away from the reality so far that it is even impossible to either confirm or falsify 
his hypotheses and bitterly comments that "[s]orry, but I preferred the doubting Theo Hermans who once wanted to check such things" (1998, p. 109).

The research on the translation of erotic literature appears to be very scarce; not to mention the research on the norms in the translation of erotic literature. The studies closest to the one presented here are perhaps the ones performed by José Santaemilia: "The Translation of Sex, The Sex of Translation: Fanny Hill in Spanish" (2005), "Researching Sexual Language: Gender, (Im)Politeness and Discursive Construction" (2006) or "The Translation of Sex-Related Language: The Danger(s) of Self-Censorship(s)" (2008). For instance, in the last article J. Santaemilia deals with the translation of sex-related language in the context of both social and personal boundaries and translator's self-censorship(s), "which are not explicitly imposed, but that the translators find necessary to safeguard their professional status or their socio-personal environment" (Santaemilia, 2008, n.p.). The author focuses especially on the translation of the lexeme "fuck" in Bridget Jones and Bridget Jones into Spanish and Catalan. The analysis shows that while the Spanish translator translates "fuck" nearly automatically, predominantly using "joder," the Catalan translator opts for more varied, natural and marked options. J. Santaemilia assumes that one of the potential explanations is that Catalan people generally view themselves as more at ease with cursing and swearwords than the Spanish $(2008$, n.p.).

\section{ANALYSED SOURCES}

The first step of the analysis was to select appropriate texts. Our baseline condition was to find works which were: a) translated within the same period of time (after 2010); b) translated by different translators, and c) published by different publishing houses. This allowed us to eliminate possible habits and patterns of language use of a particular translator and to circumvent the impact of internal norms and regulations of a given publishing house on the shape of the target text.

In the end, our study comprised three pairs of English novels and their Polish translations. The first pair was Sylvia Day's Bared to You (2012a) and its Polish translation Dotyk Crossa (2012b). According to S. Day's official website, she is an award-winning author whose books were bestsellers in 28 countries and who sold millions of copies in forty-one languages ("Meet Sylvia", n.d.). Bared to You is the first part of Crossfire series, which tells a story of a relationship between Eva Trammel, a young advertising worker, and Gideon Cross, a billionaire. They are connected by a passionate relationship but as it turns out, they share also some past traumatic experiences as they were both victims of abuse in their childhood. After its publication, the novel was announced "fastest selling paperback for a decade" (Page, 2012) and was found among ten top-selling books in the United States in both 2012 and 2013 ("St. Martin's Press Acquires \#1 New York Times Bestselling Author Sylvia Day," 2014). The book was translated into Polish by Ksenia Sadowska and published by Wielka 
Litera. Sadowska was not found to be a translator of other literature except for the Crossfire series. The second pair was Megan Hart's Tempted (2007) and its Polish translation Trzy oblicza pożadania (2012). Megan Hart is another New York Times Best-Selling Author. The book, Tempted, is the first in the series entitled Alex Kennedy. The plot focuses on Anne, her husband James, and his mysterious best-friend Alex, who suddenly disappeared from James' life many years ago to reappear now and to engage Anne and James in a complicated, three-way relationship, both sexually and emotionally. It was translated into Polish five years after its publication. The translation was commissioned by Wydawnictwo Mira, which is a brand of Harlequin Enterprises. The translator was Bogusław Stawski, who appears to be an active translator of literature, though his last works comprise mostly crime and thriller novels (esensjopedia, n.d.). The third pair comprises The Ivy Lessons (2012) by J. Lerman (penname of Susanna Quinn) and its translation Uwięziona w bluszczu (2014) published by Wydawnictwo Amber. The Ivy Lessons is the first part of the series Devoted it was Amazon's \#1 Best-Seller in the Erotica category (Wydawnictwo Amber, n.d.). The novel offers a story of Sophie, a young student of acting, and Marc, Hollywood star running an acting school. The two quickly establish a student-master relationship that goes beyond their academic interests. The book was translated by Barbara Kwiatkowska, who appears to be a prolific translator of erotic and romance novels (lubimyczytac.pl, n.d.).

All sources were analysed quantitatively with the application of corpus-based tools and qualitatively with the application of G. Toury's Descriptive Translation Studies (DTS) research.

\section{QUANTITATIVE ANALYSIS}

Once the selection of sources was finished, we parsed the texts into corpora and selected the taboo words that occur in erotic literature in general. Their occurrences are almost exclusive to: a) words related to carnal activity itself or the body parts involved therein, and b) words used in order to intensify/ emphasise utterances. We tagged both a) and b) and analysed only the former category. The types (words) we analyse quantitatively were selected based on the number of their respective tokens that appeared in the wordlists for Polish and English. We required at least two tokens to occur for each type for the lemma of that type to be included into the dataset.

\section{CATEGORISING WORDS AND EXPRESSIONS RELATED TO CARNAL ACTIVITY}

The next step to analysing the corpora required us to categorise the taboo-related vocabulary. In his study of swearword use in English, Tony McEnery (2006, p. 30) hinges his research on a five-degree scale of offence based on the British Board of Film Classification. While T. McEnery works with a large 
monolingual corpus, our research examines how words behave in translation. Comparing the intermediate levels of the two complex scales cross-linguistically would inherently involve a significant degree of fuzziness. As to avoid this, we decided to simplify the scale by dividing the words into marked and unmarked. We based the division on the existing dictionaries of English and Polish: Merriam-Webster Dictionary of English, Oxford English Dictionary and Słownik Języka Polskiego [Dictionary of the Polish Language]. We categorised words as unmarked if the dictionaries defined them as "neutral," "formal," or "medical." Consequently, we categorised words as marked if they were defined as "offensive," "vulgar" and "informal." Due to the simplified approach to the scale, words from our corpora fit their respective categories unambiguously. The results of this division for Polish can be found in Table 1, whereas the results for English can be found in Table 2:

Table 1.

Categorisation of taboo vocabulary from the Polish corpus

\begin{tabular}{ll}
\hline Categorisation & Words in the category \\
\hline Marked & szparka, cipka, kutas, chuj, drag, pieprzyć (sié), pierdolić (się), ruchać (się) \\
Unmarked & wagina, techtaczka, penis, członek, męskość, brać, kochać się \\
\hline
\end{tabular}

Source: own research.

Table 2.

Categorisation of taboo vocabulary from the English corpus

\begin{tabular}{ll}
\hline Categorisation & Words in the category \\
\hline Marked & clit, pussy, cunt, cock, dick, prick, shaft, to fuck \\
Unmarked & vagina, clitoris, penis, to make love
\end{tabular}

Source: own research.

When comparing the vocabulary, a significant difference appears between the marked category words for the carnal activity itself: erotic fiction in English almost exclusively uses the word "fuck" to refer to it whereas Polish commonly uses three expressions which vary in strength: "pieprzyć," "ruchać" and "pierdolić," the final one being arguably the strongest. Another difference is in the number of Polish unmarked expressions which share the denotation of the English word "penis"; "członek" was the most common unmarked denotator (72 occurrences), "penis" being second (36 occurrences) and "męskość" (which is arguably the mildest and only occurred twice).

\section{MEASURING THE LINGUISTIC VARIETY IN THE ORIGINALS AND IN TRANSLATIONS}

The examination of the translations via corpus methods was somewhat limited by the fact that the erotic fiction is traditionally written in first person which significantly influences the data obtained from the text itself. We do not have a large 
enough corpus of first-person translated fiction for comparison. Hence, we decided to carry out a simple Standardised Type-Token Ratio analysis to examine how varied the translators' vocabulary was (see Table 3). The corpora were not lemmatised for this procedure so the numbers for Polish are naturally inflated due to the number of possible inflections Polish words may carry.

Interestingly, two of the translations have very high vocabulary variety; it is on the same level as the mean STTR of Polish translated fiction texts, for which STTR equals 38.4 (Olejniczak, 2016, p. 143). Both Bared to You and Tempted appear to be complex and solid on the linguistic level despite the fact that erotic fiction has the reputation of being poorly written. Ivy Lessons, on the other hand, visibly stands out as the text with the least variety in terms of vocabulary for both the ST and the TT. STTR of 32.12 is extremely low (no translated literary fiction is even remotely this low in the corpora available to us); STTR this low is thus a reliable indicator that the text is severely lacking in terms of vocabulary. It has to be mentioned, however, that the STTR analysis does not provide any in-depth information about the causes. We can assume, however, that at least two of the texts we analyse remain on a literary level similar to regular fiction translated from English into Polish.

\section{TABOO VOCABULARY IN TRANSLATION}

In the core section of the quantitative part of this analysis, we chose to examine the relationship between the count of marked and unmarked expressions related to sex in the English source texts and the Polish target texts. The analysis relies on the categorisation described in Tables 1 and 2.

Firstly, our analysis aims to examine whether the distribution of marked and unmarked taboo vocabulary differs significantly between English source texts and their Polish translations. Tables 4 and 5 represent data distribution for the vocabulary denoting male and female genitals.

\section{Table 4.}

The distribution of marked and unmarked vocabulary items related to male genitals in the source and target texts

\begin{tabular}{cccc}
\hline EN Marked & Count & PL Marked & Count \\
\hline Cock & 95 & Kutas & 19 \\
Dick & 12 & Chuj & 3 \\
Prick & 14 & Drąg & 3 \\
Shaft & 4 & & \\
Total & 125 & Total & 25 \\
\hline EN & \multicolumn{3}{c}{ PL } \\
Unmarked & Count & Unmarked & Count \\
\hline Penis & 18 & Penis & 35 \\
& & Członek & 72 \\
& & Męskość & 2 \\
Total & 18 & Total & 109 \\
\hline
\end{tabular}

Source: own research 
Despite the fact that Polish has a number of marked words that denote the word "penis," all three translators startlingly opted for the unmarked denotators or for omission of the term altogether in the vast majority of the cases. Out of 125 marked uses in the STs, only 25 such marked expressions appeared in the TT. The only consistent relationship that was retained is the use of the word "shaft" in English and "drag" in Polish, which can be attributed to the fact that these expressions use the same conceptual metaphor. The denotator most commonly used in Polish translation, "członek," is a neutral word which is quite commonly used in the medical context. The word "cock," which is the most common word in English source texts, is clearly informal and does not usually occur in medical contexts.

In terms of the expressions used to describe female genitals, we observed a similar pattern. In this case, some of the data can be explained by the fact that Polish does not have an unmarked expression that can refer to the word "clitoris" while English does, rendering the word "clit" linguistically untranslatable (as per Catford 1965, p. 94). This forced the translator to use

\section{Table 5.}

The distribution of marked and unmarked vocabulary items related to female genitals in source and target texts

\begin{tabular}{lclc}
\hline EN Marked & Count & PL Marked & Count \\
\hline Clit & 49 & Szparka & 5 \\
Pussy & 13 & Cipka & 17 \\
Cunt & 17 & & \\
Total & 79 & Total & 22 \\
\hline EN Unmarked & Count & PL Unmarked & Count \\
\hline Vagina & 5 & Wagina & 9 \\
Clitoris & 6 & Łechtaczka & 58 \\
Total & 11 & Total & 67 \\
\hline
\end{tabular}

Source: own research

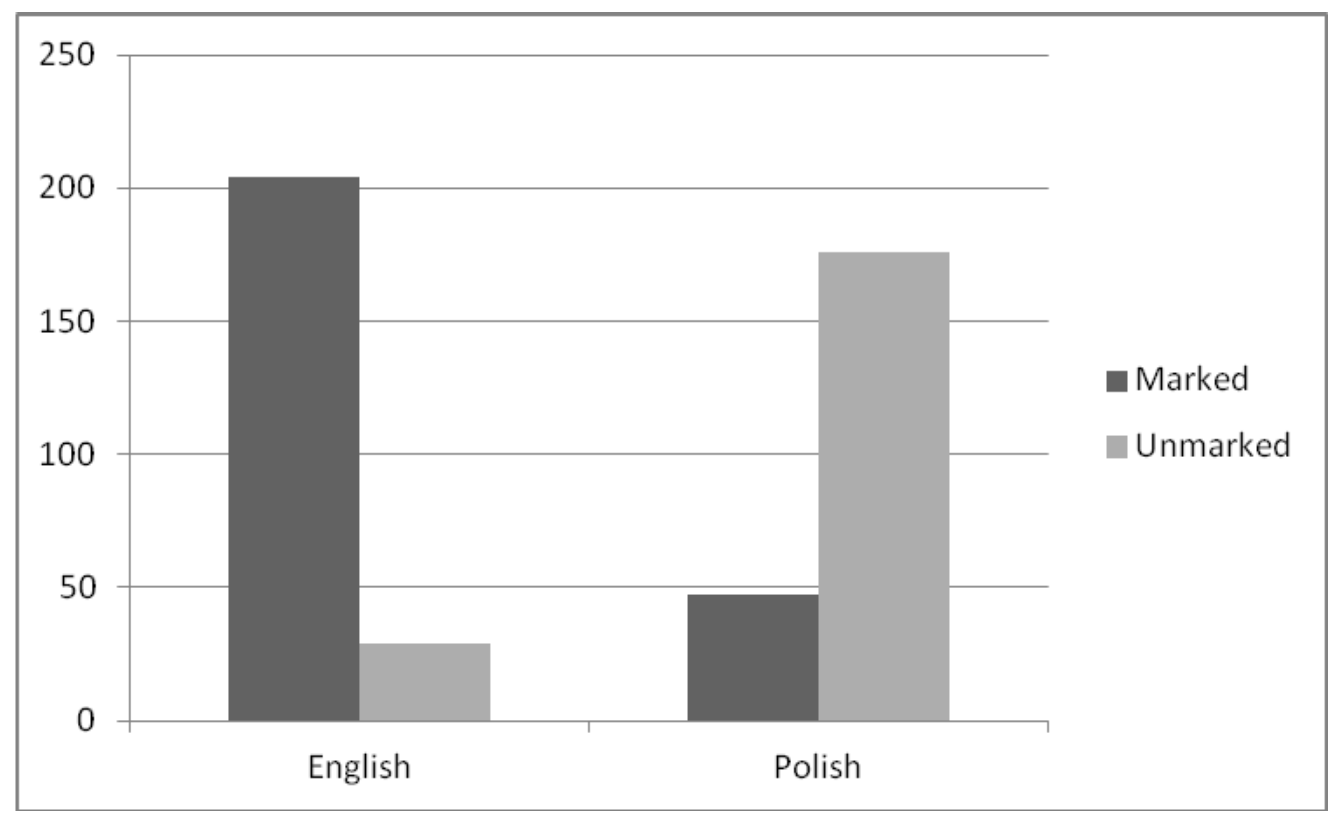

Figure 1.

The comparison of the distribution of marked and unmarked vocabulary items related to male and female genitals in source and target texts

Source: own research 
the closest existing equivalent, which happened to be unmarked. While the linguistic context does indeed explain this segment of the data, it does not take away from the fact that in the Polish translations the vast majority of the words related to genitals remains unmarked. Combined data from tables 4 and 5 are represented in Figure 1.

The contrast in the distribution of marked and unmarked expressions is very significant. It is very clear that the translations examined had a very strong tendency to make the taboo vocabulary more neutral. This is further emphasised by the use of the marked word "fuck" which appears 139 times in the corpus to refer to carnal activity (the 72 emphatic uses were not counted). This number is matched by 75 occurrences of the Polish marked words (62 "pieprzyć się," 9 "pierdolić" and 4 "ruchać"). 64 occurrences of the verb "to fuck" in the ST are not accounted for in the TT at all. Qualitative analysis indicates that translators chose to circumvent the use of marked words in translation by paraphrase and omission. The unmarked expression "to make love" and its Polish counterpart "kochać się" were both used 23 times, which indicates that this particular phrase was not used to substitute the marked expression.

\section{QUALITATIVE ANALYSIS}

Descriptive Translation Studies (DTS) comprises a set of directives proposed by G. Toury (1995) on how to approach the study of translation. There are numerous possible variants, including the study of solely target text, the study of target texts in more than one language, or the study of both source and target texts. In this article, we will discuss briefly only the comparative study of source and target texts.

Perhaps the most unsettling issue when it comes to the comparative analysis of translation is what exactly should be compared. According to G. Toury (1995), it is most important to define exactly which aspects should be compared as these aspects are going to ultimately determine the shape of the analysed material. Upon the choice of translational issue that is going to be analysed, proper segments of source text displaying the issue can be selected for the analysis. Then, regarding the choice of corresponding parts of the target text, "the analyst will go about establishing a segment of the target text, for which it would be possible to claim that - beyond its boundaries - there are no leftovers of the solutions to a translation problem which is represented by one of the source text's segments" (Toury, 1995, p. 79). In the result, the study is based on "a series of (ad hoc) coupled parts of replacing + replaced segments" (Toury, 1995, p. 77) created on the basis of the common translational issues and solutions thereto. The study of a proper number of such ad hoc coupled parts is supposed to unveil certain repeating patterns in the translation, which are potential translational norms. 
In this study, our main concern was how the sensitive and sex-related language is rendered in the Polish translations. The analysis of the coupled parts from the six above-mentioned sources revealed certain tendencies in translation. ${ }^{1}$ Some of the examples can be found in the table below:

\section{Table 6.}

Paired couples of source and target texts presenting the issue of translation of sensitive and sex-related language

\begin{tabular}{lll}
\hline No. & Source text & Target text \\
\hline 1. & Using both hands, Gideon commanded & Teraz Gideon obiema dłońmi nadawał \\
my rhythm, tilting me into an angle that & mi rytm, odchylając mnie tak, że główka \\
had the big crown of his cock rubbing & penisa pocierała czuły, drażliwy punkt \\
$\begin{array}{l}\text { a tender, aching spot inside me (Day, } \\
\text { 2012a). }\end{array}$ & wewnątrz mnie (Day, 2012b). \\
\hline
\end{tabular}

2. My cunt felt swollen, embracing his Miesśnie pochwoy miałam napięte, ściśle erection, taking him all the way into my obejmowały jego członek (Hart, 2012). body (Hart, 2007).

3. I'd been with boys who assumed a few Byłam $\mathrm{z}$ chłopakami, którzy myśleli, że moments of fingering were enough to kilka ruchów palcami doprowadzi mnie do send me into ecstasy (Hart, 2007) ekstazy (Hart, 2012)

4. I do, and gasp as I feel him against me, Robię to i gwałtownie chwytam hardness against my buttocks. I see a powietrze, bo czuję go na sobie, czuję glimmer of something, and the flash of a jego twardy penis na moich pośladkach condom packet (Lerman, 2012). (Lerman, 2014).

5. At first I couldn't look at his penis, and I closed my eyes to nuzzle his thighs as I Opuściłam powieki, by opóźnić ten moment. Członek w zwodzie zaczepił pushed his jeans to the floor where he stepped o moje włosy, otarł się o policzek (Day, out of them. His erection brushed my hair, 2012b).

then my cheek, and I ran my hands along the backs of his calves and knees (Day, 2012a)

6. If Cary walked in right then and found me writhing in our living room while Gideon finger-fucked me, I didn't think I'd care (Day, 2012a)

Gdyby do pokoju wszedł teraz Cary, stając się świadkiem spektaklu w naszym salonie, gdzie ja naga wije się w konwulsjach na kanapie, podczas gdy Gideon robi mi palcówkę, chyba nawet by mnie to nie obeszło (Day, 2012b).

7. "Fuck, fuck, fuck," he growled, - Jeb, jeb, jeb - zawył, dźgając biodrami pounding his hips up at me, yanking my hips down to meet his punishing lunges. He hit the end of me with every deep thrust, battering into me. I could feel him growing harder and thicker (Day, 2012a). $\mathrm{w}$ górę $\mathrm{i}$ jednocześnie pociągając mnie $\mathrm{w}$ dól, by poraziła mnie petna sita jego zabójczej szarży. Docierał do samego krańca każdym głębokim pchnięciem, smagając mnie, bombardując moje wnętrze, zmuszając do uległości. Czułam, jak nabrzmiewa, jak rośnie wszerz i wzdłuż, do granic możliwości.

Source: own compilation.

1 Due to the somewhat low amount of the analysed material, we refrain from calling these tendencies 'norms' as more research is required. 
The analysed excerpts show the following three main tendencies: neutralisation, deletion and addition. The first three examples display how neutralisation can be assumed through the application of different translation strategies. In the first example, the marked word "cock," classified by Cambridge Dictionary as offensive, is replaced with neutral and biological term "penis." Similarly, in the second example, the marked word "cunt" appears, defined in the Urban Dictionary as "extremely offensive" (Urban Dictionary, 2019). In the Polish translation, the word is replaced with "mięśnie pochwy," hence another neutral and biological term. Interestingly, in the same example, English "him" referring implicitly to a penis is replaced in the Polish text with explicit reference "członek," hence another highly neutral term for penis. In the third example, the neutralisation also takes place, however through the means of a different strategy, namely description. Highly sexual term "fingering" is replaced in translation with the phrase "kilka ruchów palcami," which could be back translated as "several finger moves." This strategy is reminiscent of the descriptive equivalent, which is one of the possible techniques in the translation of culturally-bound items (Hejwowski, 2004). The aim of the technique is to remove a potentially foreign or unknown term and replace it with a description. Here, it is applied in order to remove marked term and replace it with neutral description.

Examples 4 and 5 illustrate the case of deletion: the parts in italics do not appear in the target text. Interestingly, the deleted parts are not as highly marked as the rest of the text which remained in translation. What is more, the deleted part in the example 4-"I see a glimmer of something, and the flash of a condom packet" - is clearly an excerpt performing a positive function of the promotion of sexual health. Similar situation takes place in Day's Bared to You, when the theme of contraception appears, the sentence "I'll prove to you I'm clean and you'll do the same, then you're going to let me come in you" (2012a, n.p.) uttered by Gideon turns in translation "Dowiodę ci, że jestem w porządku. Ty zrobisz to samo, a potem pozwolisz mi, żebym w ciebie wszedl" (2012b, n.p.), perhaps due to the misunderstanding of the source text. This example is not a subject of our analysis as it is not part of the material that serves our criteria, yet it displays the same issue: a part related to sexual health (here, getting checked for sexually-transmitted diseases before engaging in an unprotected intercourse) is removed in translation. This trend seems to be unsettling as the promotion of sexual health is without any doubt a positive aspect of this literary genre, especially that some teenagers and young adults may gain their knowledge on the sexual life on the basis of this literature.

Finally, the last tendency that appeared is addition. Perhaps the additions were supposed to make up for other deleted fragments. Interestingly, the added fragments present very specific poetics: the language is highly emphatic, unusual. The back translation of the added fragments would be as follows:

- "stając się świadkiem spektaklu" - becoming the witness to our spectacle;

- "gdzie ja naga wiję się w konwulsjach na kanapie" - where I writhe, naked, convulsively on the couch; 
- "poraziła mnie pełna siła jego zabójczej szarży" - smitten by the full power of his lethal charge;

- "smagając mnie, bombardując moje wnętrze, zmuszając do uległości" lashing me, bombarding my inside, and forcing me to submission;

- "jak rośnie wzdłuż i wszerz, aż do granic możliwości" - how he grows in length and breadth, up to the breaking point.

Hence, these are all fragments that do not change the meaning but highly influence the modality and poetics of the text, romanticising the situation of the sexual encounter.

\section{CONCLUSIONS}

To sum up, the quantitative analysis indicates a strong trend for the Polish translators to opt out of marked expressions in favour of a) unmarked ones and b) omission/paraphrase strategies. Taking into consideration the degree to which the sex-related language transitions from marked to unmarked, we firmly believe that these changes influence the reception of the target text on pragmatic level. This trend is further confirmed by the qualitative analysis, as the main occurring tendencies are neutralisation (hence, either the exchange of marked vocabulary for an unmarked one or paraphrase), omission or, interestingly, addition, which also seems to influence significantly the poetics of the text.

It remains to be discovered, however, what the motive is behind making these very pronounced changes during the translation process. We stipulate that indeed, some part of these changes may have been introduced as a part of the editorial process for the finalised translations or through the publishing houses' internal guidelines and regulations. The "marked-to-unmarked" shifts are, however, very consistent across the works we examined thus far despite the differences in both translators and publishing houses involved, which may be indicative of the fact that the translators are committing self-censorship. This final point is of paramount importance because, if it is indeed true, it might allow for further research into how sex is framed linguistically in Polish in contrast to other languages. Such research, we presume, would involve expanding the scope of research to more numerous works and then conducting interviews with translators to discover what exactly leads them to introducing the "marked-to-unmarked" shifts as frequently and as consistently as they did.

\section{REFERENCES}

1. Barbara Kwiatkowska on lubimy czytać.pl (n.d.). Retrieved from http://lubimyczytac.pl/ tlumacz/12394/barbara-kwiatkowska.

2. Bogustaw Stawski - esensjopedia (n.d.). Retrieved from https://esensja.pl/esensjopedia/obiekt. html?rodzaj_obiektu=11\&idobiektu=20069.

3. Bukowski, P., \& Heydel, M. (2009). Współczesne teorie przekładu. Antologia. [Modern translation theory. An anthology]. Kraków: Znak. 
4. Catford, J. C. (1965). A linguistic theory of translation: An essay in applied linguistics. Oxford: Oxford University Press.

5. Chesterman, A. (1998). Description, Explanation, Prediction: A Response to Gideon Toury and Theo Hermans, Current Issues in Language and Society 5(1-2), 91-98. DOI: 10.1080/13520529809615505.

6. Day, S. (2012a). Bared to you: A Crossfire novel. E-book edition. Wildomar: Sylvia Day.

7. Day, S.(2012b). Dotyk Crossa (K. Sadowska, Trans.). E-book edition. Warszawa: Wielka Litera.

8. DeLamater, J. (1981). The social control of sexuality. Annual Review of Sociology, 7, 263-290.

9. Hart, M. (2007). Tempted. E-book edition. (n.p.): Harlequin.

10. Hart, M. (2012). Trzy oblicza pożadania (B. Stawski, Trans.). E-book edition. Warszawa: Mira.

11. Hejwowski, K. (2004). Translation: A cognitive-communicative approach. Olecko: Wydawnictwo Wszechnicy Mazurskiej.

12. Hermans, T. (1996). Norms and the Determination of Translation. A Theoretical Framework. In: R. Álvarez, \& M. Carmen-África Vidal (Eds.), Translation, Power, Subversion (pp. 25-51). Clevedon: Multilingual Matters.

13. Hermans, T. (2009 [1997]). Translation in Systems. Descriptive and System-oriented Approaches Explained. Manchester: St. Jerome Publishing.

14. Lerman, J. (2012). The Ivy Lessons. E-book edition. (n.p.): Kindle Unlimited.

15. Lerman, J. (2012). Uwięziona w bluszczu (B. Kwiatkowska, Trans.). E-book edition. Warsaw: Wydawnictwo Amber.

16. McEnery, T. (2004). Swearing in English: Bad language, purity and power from 1586 to the present. London and New York: Routledge.

17. Meet Sylvia. (n.d.). Retrieved from: https://www.sylviaday.com/about/.

18. Olejniczak, J. (2016). Interference Patterns of the Verb Say in the Narration of English-Polish Literary Translations: A Corpus-Based Study. ANGLICA-An International Journal of English Studies, 25(2), 139-150.

19. Page, B. (2012,July 23). Penguin declares Day its 'newerotic brand sensation'. Retrieved from https:// www.thebookseller.com/news/penguin-declares-day-its-new-erotic-brand-sensation.

20. Pym, A. (1998). Okay, So How Are Translation Norms Negotiated? A Question for Gideon Toury and Theo Hermans. Current Issues in Language and Society 5(1-2), 107-113.

21. Santaemilia, J. (2005). The Translation of Sex, The Sex of Translation: Fanny Hill in Spanish. In: J. Santaemilia, (ed.), Gender, Sex and Translation: The Manipulation of Identities (pp. 117-136). Manchester: St. Jerome.

22. Santaemilia, J. (2006). Researching Sexual Language: Gender, (Im)Politeness and Discursive Construction. In: P. Bou (ed.), Ways into Discourse (pp. 93-115). Granada: Editorial Comares.

23. Santaemilia, J. (2008). The Translation of Sex-Related Language: The Danger(s) of Self-Censorship(s). TTR: Traduction, Terminologie, Rédaction 21(2). DOI: https://doi. org/10.7202/037497ar.

24. St. Martin's Press Acquires \#1 New York Times Bestselling Author Sylvia Day (2014, January 16). Retrieved from: https://www.prnewswire.com/news-releases/st-martins-press-acquires1-new-york-times-bestselling-author-sylvia-day-240488161.html.

25. Toury, G. (1995). Descriptive Translation Studies - and beyond. Amsterdam/Philadelphia: John Benjamins.

26. Uwięziona w bluszczu (n.d.). Retrieved from http://www.wydawnictwoamber.pl/kategorie/ beletrystyka/erotyka/uwieziona-w-bluszczu,p1548. 